\title{
Analiza numeryczna procesu spawania wielościegowego złącza teowego oraz obróbki cieplnej po spawaniu
}

\author{
Numerical analysis of multipass T-joint welding \\ and post welding heat treatment
}

\section{Streszczenie}

W prezentowanej pracy przeprowadzono analizę numeryczną spawania i obróbki cieplnej po procesie spawania wielościegowego złącza teowego blach ze stali S355J2G3 o grubości $10 \mathrm{~mm}$. Przeprowadzono kompletną analizę termo-metalurgiczną oraz mechaniczną dwóch wariantów spawania: z podgrzewaniem wstępnym i bez podgrzewania. Wykazano wpływ zastosowanej obróbki cieplnej oraz podgrzewania wstępnego na rozkłady faz metalurgicznych w analizowanych złączach jak również rozkłady twardości, odkształceń i naprężeń. Przedstawione wyniki analiz numerycznych wykazały szeroki zakres informacji o procesie, które użytkownik otrzymuje a część z nich jest albo nieosiągalna albo bardzo złożona do uzyskania w tradycyjny sposób, w trakcie badań laboratoryjnych. Analizy numeryczne przeprowadzone zostały w programie VISUAL WELD (SYSWELD) firmy ESI Group.

Słowa kluczowe: analizy numeryczne, MES, SYSWELD, odkształcenia spawalnicze, naprężenia spawalnicze, obróbka cieplna po spawaniu

\begin{abstract}
In presented work, results of numerical simulations of welding and post weld heat treatment (PWHT) of multi pass t-joint of S355J2G3 steel $10 \mathrm{~mm}$ thick plates were presented. Complete thermo-metallurgical and mechanical analyses were done with two welding variants: with and without PWHT. Results presentation was focused on the influence of PWHT and preheating on metallurgical phases, hardness, distortions and stresses distribution. Presented analyses results gives also wide range of additional process information's which can be achieved during the numerical simulations and can be unavailable or difficult to collect using conventional measurements method. All presented analyses were done in VISUAL WELD (SYSWELD) produced by ESI Group.
\end{abstract}

Keywords: numerical simulations, FEM, SYSWELD, welding distortions, welding stresses, post weld heat treatment

\section{Wstęp}

Procesy spawania, jako najczęściej wykorzystywana technika łączenia elementów konstrukcji i maszyn, dodatkowo komplikują proces ich konstruowania. Nowe materiały i oddziaływujący na nie cykl cieplny towarzyszący spawaniu powoduje powstawanie naprężeń i odkształceń po spawaniu ale również niekorzystnych zmian metalurgicznych w strukturze spawanych materiałów. Rodzaj i rozkład naprężeń oraz odkształceń zależny jest o wielu czynników - sposobu umocowania elementów do spawania, właściwości mechanicznych i cieplnych, rodzaju użytej technologii, parametrów procesu spawania, rodzaju zaprojektowanych złączy, temperatur otoczenia i podgrzewania itp. Uzyskanie niekorzystnego rozkładu naprężeń po procesie spawania, które w normalnych warunkach tworzą zrównoważony układ sił wewnętrznych, może mieć negatywne skutki w postaci obniżenia trwałości konstrukcji jak również skłonności do zmian właściwości w trakcie ich eksploatacji. Również odkształcenia podczas oraz po spawaniu mogą być wynikiem niedotrzymania założonych odchyłek wymiarowych.
Wiąże się to z koniecznością stosowania dodatkowych zabiegów naprawczych jak chociażby prostowanie, co pod-

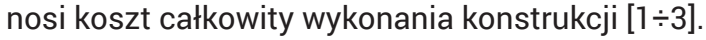

Aby uzyskać wyrób odpowiadający wymaganiom, istnieje więc konieczność posiadania obszernej wiedzy dotyczącej zachowania się materiałów poddanych cyklowi cieplnemu procesu spawania. Takie dane wymagają nie tylko szerokiej wiedzy ale również często posiadania dostępu do szerokiego zakresu badań laboratoryjnych dotyczących właściwości mechanicznych jak i cieplno-metalurgicznych stosowanych materiałów. Również wiedza dotycząca samego procesu spawania, odpowiedni dobór warunków brzegowych stanowi spore wyzwanie przed inżynierami decydującymi się na zastosowanie tej dziedziny wiedzy w swoich praktycznych opracowaniach $[2 \div 6]$.

Symulacja numeryczna procesów spawania jest zatem jednym z bardziej złożonych zagadnień w zakresie analiz prowadzonych przy użyciu metody elementów skończonych. Wynika to z szeregu czynników składających się

Dr inż. Tomasz Kik; mgr inż. Bernard Wyględacz - Politechnika Śląska; dr inż. Marek Slováček - MECAS ESI, Brno, Czech Republic.

Autor korespondencyjny/Corresponding author: tomasz.kik@polsl.pl 
na sam proces i konieczności ich uwzględnienia w prowadzonych obliczeniach [2:4].

Jednakże nawet posiadanie szerokiej wiedzy teoretycznej popartej nieraz szerokimi badaniami laboratoryjnymi nie jest wystarczającym warunkiem uzyskania wysokiej dokładności wyników analiz numerycznych z zastosowaniem przypadkowych narzędzi. Kluczową rolę odgrywa w tym przypadku oprogramowanie i zakres czynników wejściowych branych pod uwagę w jego działaniu. Wprowadzenie na rynek zaawansowanych pakietów umożliwiających prowadzenie obliczeń z wykorzystaniem metody elementów skończonych tworzy „nową jakość” w projektowaniu niezliczonych odmian detalu celem dążenia do uzyskania maksymalnej jakości, trwałości oraz określonych cech użytkowych. Dodatkowa „specjalizacja” tych pakietów pozwala na znacznie bardziej elastyczne i pełne wykorzystanie ich w tych gałęziach przemysłu, do których zostały one przeznaczone $[2,4]$.

Nowoczesne programy do analiz numerycznych procesów spawania, bazujące na metodzie elementów skończonych, znacznie zmieniły możliwości jakimi dysponuje dzisiaj inżynier spawalnik. Istnieje możliwość całkowicie wirtualnego określania struktur metalurgicznych, odkształceń i naprężeń spawalniczych, na wczesnym etapie projektowania produktu lub opracowywania technologii spawania. Istnieje zatem możliwość wprowadzania zmian w procesie zanim dokonane zostaną zmiany w procesie wytwarzania jak również testowania różnych wariantów danego rozwiązania tj. kolejność spawania, zmiana temperatury podgrzewania wstępnego, zastosowanie obróbki cieplnej po spawaniu. W prosty sposób, poprzez ograniczenie do minimum koniecznych do wykonania prób i prototypów, obniżamy zatem koszty wytwarzania jak również uzyskujemy dodatkowe informacje opracowując optymalną technologię [6 $\div 11]$.

\section{Narzędzia obliczeniowe}

Obecnie na rynku istnieje wiele rozwiązań w postaci oprogramowania, które w mniejszym lub większym zakresie pozwala na prowadzenie analiz zjawisk zachodzących w trakcie spawania elementów konstrukcyjnych. W analizach opisanych w artykule, wykorzystano pakiet VISUAL WELD (SYSWELD) firmy ESI Group. Jest to oprogramowanie pozwalające na prowadzenie symulacji metodą elementów skończonych, obejmujące swoim obszarem zagadnienia spawania oraz obróbki cieplnej. VISUAL WELD (SYSWELD) pokrywa w całości problematykę analiz nieliniowych tj. nieliniowe przewodzenie ciepła w każdej przestrzeni, nieliniowa geometria wielkich odkształceń, izotropowe i kinematyczne umocnienie materiału czy przemiany fazowe. Połączenie wpływu tak dużej liczby zjawisk występujących w procesie spawania pozwala na uzyskanie wysokiej zgodności wyników symulacji z rzeczywistym zachowaniem spawanej konstrukcji [2,4].

VISUAL WELD (SYSWELD) umożliwia symulację procesów spawania $\mathrm{w}$ bardzo szerokim zakresie: zarówno bez materiału dodatkowego jaki i z materiałem dodatkowym, za pomocą źródeł ciepła mających kontakt fizyczny ze spawanym elementem (zgrzewanie tarciowe, punktowe) jak również bez kontaktu (łuk elektryczny, wiązka laserowa, wiązka elektronów). Podobnie szeroki jest zakres możliwej do przeprowadzenia obróbki cieplnej. Są to procesy m.in.: odpuszczania, wyżarzania odprężającego, przesycania, hartowania (laserowego, indukcyjnego, wiązką elektronów, plazmowego, tarciowego), nawęglania i azotowania [4].

Dane wejściowe procesu obliczeniowego stanowią w skrócie wszystkie informacje, które inżynier spawalnik znajdzie w Instrukcji Technologicznej Spawania oraz które na podstawie własnego doświadczenia zawodowego jest w stanie podać. Istotne są również wyniki, które dzięki przeprowadzeniu symulacji otrzymujemy. W tym przypadku możliwe jest uzyskanie rozkładów pola i gradientów temperatur, zawartości faz w poszczególnych obszarach złącza, odkształceń, naprężeń własnych, przemieszczeń oraz twardości $[2,3,8,9,10]$.

W uzyskaniu wyników o bardzo wysokim stopniu korelacji z rzeczywistym zachowaniem się detalu/konstrukcji istotne są dane materiałowe jakimi dysponuje oprogramowanie. Zazwyczaj właściwości mechaniczne są definiowane jako funkcje zależne od temperatury oraz zawartości poszczególnych faz. Obok danych cieplno-mechanicznych materiału tj. współczynnik przewodnictwa cieplnego, ciepło właściwe/entalpia, gęstość, moduł Younga, współczynnik Poissona, granica plastyczności czy umocnienie, istotne są również właściwości metalurgiczne. System uwzględnia przemiany fazowe, kinetykę dla przemiany austenitycznej podczas nagrzewania oraz przemiany ferrytu, bainitu i martenzytu podczas chłodzenia (wykresy CTPCs, CTPi). W przypadku konstrukcji wykonanych z aluminium uwzględniane są m.in.: przemiany z "twardego" do "miękkiego" stadium materiału odpowiadające za utratę właściwości mechanicznych, umocnienie materiału podczas eksploatacji, utrata właściwości podczas rekrystalizacji czy podczas rozpusz-

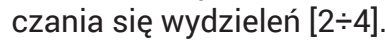

\section{Opis zagadnienia}

Zagadnienia modelowania procesów spawalniczych metodą elementów skończonych jest zagadnieniem złożonym. Określenie poziomu naprężeń spawalniczych, odkształceń, rozkładu pól temperatur jest bardzo trudne ze względu na złożony charakter zależności pomiędzy temperaturą, skurczem i rozszerzalnością cieplną oraz zmiennymi właściwościami materiału w czasie i przestrzeni. W celu uproszczenia analizy rozdziela się często analizę stanu termicznego i mechanicznego. Dzieje się tak ze względu na przyjętą zasadę: zmiany w stanie mechanicznych (naprężenia, odkształcenia) nie zmieniają temperatury procesu. Natomiast zmiana temperatury jak najbardziej ma swoje odzwierciedlenie w zmianach rozkładu odkształceń i naprężeń. Dlatego pierwsza analiza procesu spawania w takim przypadku dotyczy rozkładu pól temperatur w trakcie procesu spawania, a następnie wyniki wykorzystywane są do określenia wynikających z nich zmian w rozkładzie naprężeń i odkształceń. Taki rodzaj analizy opiera się o założenie, że ciepło generowane $w$ trakcie odkształcenia plastycznego jest znacznie mniejsze od ciepła wprowadzanego przez łuk elektryczny. Stąd też możliwe jest prowadzenie analizy termicznej i mechanicznej jako dwóch osobnych, następujących po sobie

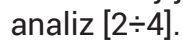

\section{Model dyskretny, założenia i wyniki analiz}

W celu przedstawienia możliwości, jakie obecnie daje spawalnikowi nowoczesne oprogramowanie, analizie numerycznej poddano model złącza teowego blach ze stali S355J2G3 (tabl. I) o grubości $10 \mathrm{~mm}$ spawanych trzema ściegami metodą MAG. Mimo że w przypadku wybranego gatunku stali oraz grubości spawanych elementów nie jest wymagane przeprowadzanie po procesie spawania obróbki cieplnej w warunkach rzeczywistych, pozwoliło to jednak pokazać możliwości oprogramowania i szeroki zakres możliwości prognozowania właściwości złączy spawanych przy zastosowaniu analizy numerycznej. 
Tablica I. Skład chemiczny stali S355J2G3 wykorzystany przy tworzeniu bazy materiałowej w programie SYSWELD Table I. Chemical composition of S355J2G3 steel used during preparing of material database in SYSWELD

\begin{tabular}{|c|c|c|c|c|c|c|c|}
\hline \multicolumn{7}{|c|}{ Skład chemiczny [\% wag.] } \\
\hline $\mathrm{C}$ & $\mathrm{Mn}$ & $\mathrm{Si}$ & $\mathrm{Cr}$ & $\mathrm{Ni}$ & $\mathrm{Cu}$ & $\mathrm{S}$ & $\mathrm{P}$ \\
\hline 0,18 & 1,6 & 0,55 & - & - & - & 0,035 & 0,035 \\
\hline
\end{tabular}

Tablica II. Parametry wykorzystane w symulacji procesu spawania wielościegowego złączy teowych blach o grubości $10 \mathrm{~mm}$ ze stali S355J2G3 metodą MAG

Table II. Welding simulation parameters of of S355J2G3 $10 \mathrm{~mm}$ thick plates T-joint MAG welding

\begin{tabular}{|c|c|c|c|c|}
\hline Nr ściegu & EPUL [J/mm] & $\mathrm{V}[\mathrm{mm} / \mathrm{s}]$ & k & $\begin{array}{l}\text { Parametry modelu } \\
\text { źródła ciepła } \\
\text { L/W/D }\end{array}$ \\
\hline 1 & 750 & \multirow{3}{*}{6} & \multirow{3}{*}{0,8} & $13 / 9 / 5$ \\
\hline 2 & 750 & & & $14 / 10 / 5$ \\
\hline 3 & 850 & & & $14 / 10 / 5$ \\
\hline \multicolumn{5}{|c|}{$\begin{array}{l}\text { Parametry obróbki cieplnej: temperatura pieca }-600^{\circ} \mathrm{C} \text {, czas nagrzewania - } 14400 \mathrm{~s} \text {, chłodzenie - na wolnym powie- } \\
\text { trzu w temperaturze } 20^{\circ} \mathrm{C}\end{array}$} \\
\hline \multicolumn{5}{|c|}{$\begin{array}{l}\text { Uwagi: EPUL (Energy per Unit Length) - energia liniowa spawania, v - prędkość spawania, k - współczynnik sprawności metody } \\
\text { spawania, parametry modelu źródła ciepła w programie SYSWELD (parametry geometryczne modelu Goldaka): L - długość jeziorka } \\
\text { ciekłego, W - szerokość jeziorka ciekłego metalu, D - głębokość wtopienia }\end{array}$} \\
\hline
\end{tabular}

W tym celu wykonano trójwymiarowym model dyskretny. Elementy spawane posiadały wymiary $100 \times 150 \times 10[\mathrm{~mm}]$ (dolna blacha) i 100x75×10 [mm] (górna blacha), rysunek 1. Siatka elementów skończonych składająca się z trójwymiarowych elementów typu solid zawierała 84244 elementy oraz 73923 węzły. Siatka została zagęszczona w obszarze złącza oraz bezpośrednio do niego przyległym w celu zwiększenia dokładności prowadzonych analiz.

Jako model źródła wybrany został model w kształcie podwójnej elipsoidy (model Goldaka), rysunek 1. Model ten został poddany wstępnie kalibracji w module „Heat Input Fitting" w celu zoptymalizowania kształtu wirtualnego jeziorka ciekłego metalu, tablica II, rysunek 2.

Warunki brzegowe odpowiadające zamocowaniu elementów zostały tak ustawione, że symulowały spawanie elementów bez dodatkowego usztywnienia. Przeprowadzone zostały zarówno analizy termiczne jak i mechaniczne dla dwóch wariantów procesu spawania: bez podgrzewania wstępnego oraz z podgrzewaniem do temperatury $150{ }^{\circ} \mathrm{C}$. Dodatkowo, na podstawie obliczonych udziałów poszczególnych faz metalurgicznych oraz składu chemicznego stali, wyliczone zostały rozkłady twardości po spawaniu oraz obróbce cieplnej. Analizie poddano zarówno wyniki analiz otrzymane z samego procesu spawania (po ostudzeniu złącza do temperatury otoczenia) jak również po przeprowadzonej
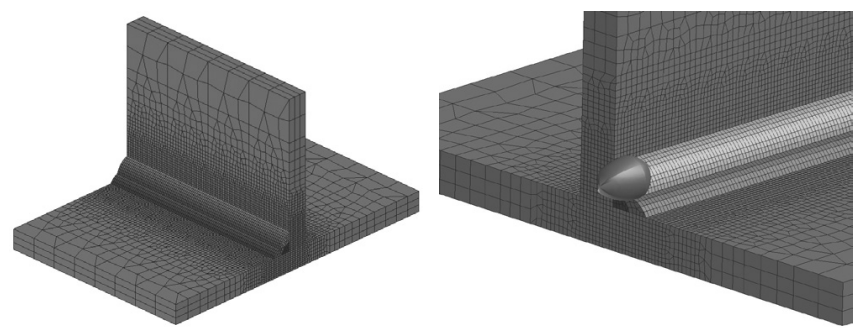

Rys. 1. Trójwymiarowy model dyskretny (po lewej) oraz widok źródła w kształcie podwójnej elpisoidy umieszczonego na trajektorii 3 ściegu (po prawej)

Fig. 1. 3D discrete model (on the left) and view of double ellipsoidal heat source on the $3 \mathrm{rd}$ bead trajectory (on the right)
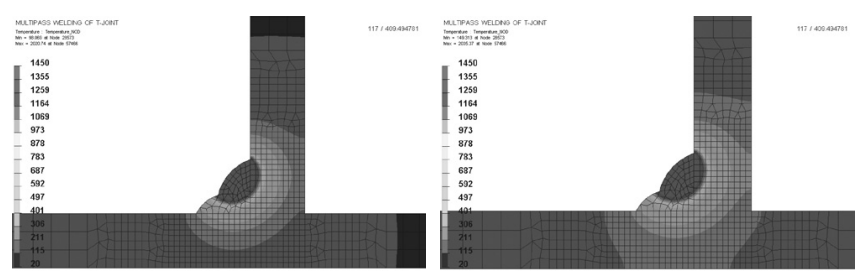

Rys. 2. Przykładowy rozkład temperatur w trakcie spawania 3-go ściegu na przekroju poprzecznym złączy teowych blach o grubości $10 \mathrm{~mm}$ ze stali S355J2G3 metodą MAG bez podgrzewania wstępnego (po lewej) oraz z podgrzewaniem wstępnym do $150{ }^{\circ} \mathrm{C}$ (po prawej)

Fig. 2. An example of temperature distributions during 3rd bead weIding on the cross section of S355J2G3 $10 \mathrm{~mm}$ thick plates T-joint MAG welded without (on the left) and with preheating up to $150^{\circ} \mathrm{C}$ (on the right)
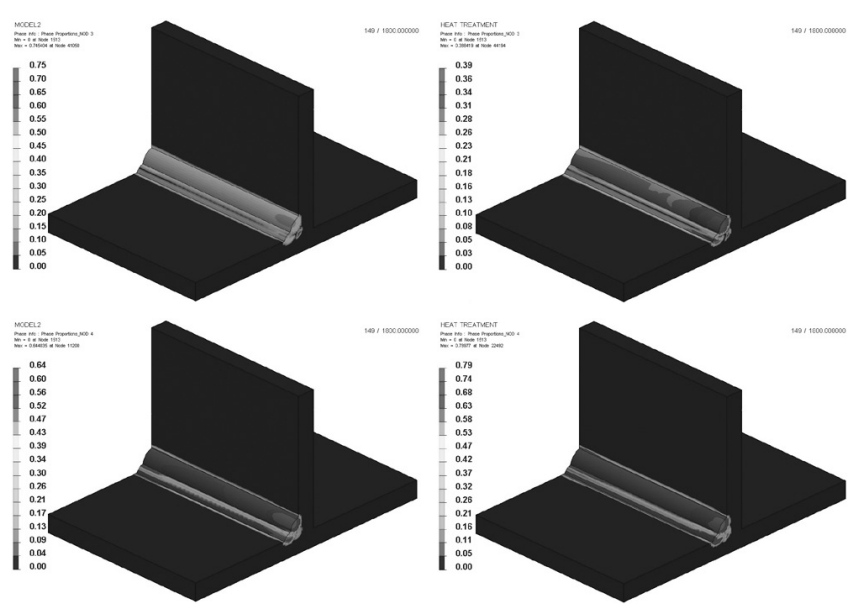

Rys. 3. Rozkład martenzytu (u góry) i bainitu (na dole) po procesie spawania złączy teowych blach o grubości $10 \mathrm{~mm}$ ze stali S355J2G3 metodą MAG bez podgrzewania wstępnego (po lewej) oraz z podgrzewaniem wstępnym do $150^{\circ} \mathrm{C}$ (po prawej), tabl. III Fig. 3. Martensite distribution (on the top) and bainite (on the bottom) of S355J2G3 $10 \mathrm{~mm}$ thick plates T-joint MAG welded without preheating (on the left) and with preheating up to $150{ }^{\circ} \mathrm{C}$ (on the right), tabl. III 
Tablica IV. Wartości minimalne i maksymalne obliczonych twardości złączy teowych blach o grubości 10 mm ze stali S355J2G3 metodą MAG po procesie spawania i obróbce cieplnej w zależności od zastosowanego wariantu technologicznego Table IV. Minimal and maximal values of calculated hardness on S355J2G3 $10 \mathrm{~mm}$ thick plates T-joint MAG welded

\begin{tabular}{|c|c|c|c|c|}
\hline Nr ściegu & EPUL [J/mm] & V [mm/s] & k & $\begin{array}{c}\text { Parametry modelu } \\
\text { źródła ciepła } \\
\text { L/W/D }\end{array}$ \\
\hline 1 & 750 & \multirow{2}{*}{6} & 0,8 & $13 / 9 / 5$ \\
\hline 2 & 750 & 6 & $14 / 10 / 5$ \\
\hline 3 & 850 & & & $14 / 10 / 5$ \\
\hline
\end{tabular}

Parametry obróbki cieplnej: temperatura pieca $-600{ }^{\circ} \mathrm{C}$, czas nagrzewania $-14400 \mathrm{~s}$, chłodzenie - na wolnym powietrzu w temperaturze $20^{\circ} \mathrm{C}$

Uwagi: EPUL (Energy per Unit Length) - energia liniowa spawania, v - prędkość spawania, k - współczynnik sprawności metody spawania, parametry modelu źródła ciepła w programie SYSWELD (parametry geometryczne modelu Goldaka): L - długość jeziorka ciekłego, W - szerokość jeziorka ciekłego metalu, D - głębokość wtopienia

obróbce cieplnej (odpuszczaniu w temperaturze $\left.600^{\circ} \mathrm{C}\right)$. Obliczenia prowadzono metodą typu „transient" czyli w sposób ciągły z podziałem na chwile czasowe oddzielone krokiem czasowym, który jest automatycznie zmieniany przez solver.

Analiza termometalurgiczna pozwoliła na określenie rozkładu i wartości poszczególnych faz metalurgicznych w analizowanych złączach zarówno po zakończeniu procesu spawania i ostudzeniu złącza do temperatury otoczenia jak również po przeprowadzonej obróbce cieplnej, tablica III, rysunek 3 i 4.

W oparciu o przeprowadzone analizy rozkładu faz metalurgicznych oraz skład chemiczny zastosowanego materiału istnieje również możliwość określenia rozkładu twardości w spawanym złączu, tablica IV. Taki wynik stanowi bardzo dobrą podstawę do prostej weryfikacji wyniku obliczeń z przykładowym złączem spawanym uzyskanym w wyniku prób.

W wyniku przeprowadzonych obliczeń mechanicznych, możliwe było również obserwowanie rozkładu odkształceń całkowitych oraz w poszczególnych osiach (kierunkach) a także naprężeń zredukowanych (zgodnie z hipotezą VonMises) oraz średnich, tablica V i VI, rysunek 5 i 6 . Dodatkowa zaletą analiz numerycznych jest również fakt, że wartości te można śledzić w sposób ciągły tj. w każdej, dowolnej chwili procesu spawania i stygnięcia złącza jak również procesu obróbki cieplnej a także w każdej osi układu współrzędnych. Takie informacje, stanowią często dodatkowe, cenne informacje dla osoby projektującej złącze lub konstrukcję.
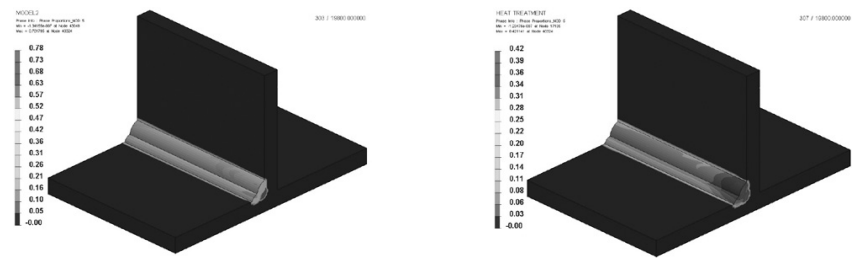

Rys. 4. Rozkład martenzytu odpuszczonego po procesie obróbki cieplnej (odpuszczania w temperaturze $600{ }^{\circ} \mathrm{C}$ ) złączy teowych blach o grubości $10 \mathrm{~mm}$ ze stali S355J2G3 metodą MAG spawanych bez podgrzewania wstępnego (po lewej) oraz z podgrzewaniem wstępnym do $150^{\circ} \mathrm{C}$ (po prawej), tabl. III

Fig. 4. Tempered martensite distribution after post welding heat treatment (in temperature $600{ }^{\circ} \mathrm{C}$ ) of S355J2G3 $10 \mathrm{~mm}$ thick plates T-joint MAG welded without preheating (on the left) and with preheating up to $150{ }^{\circ} \mathrm{C}$ (on the right), tabl. III
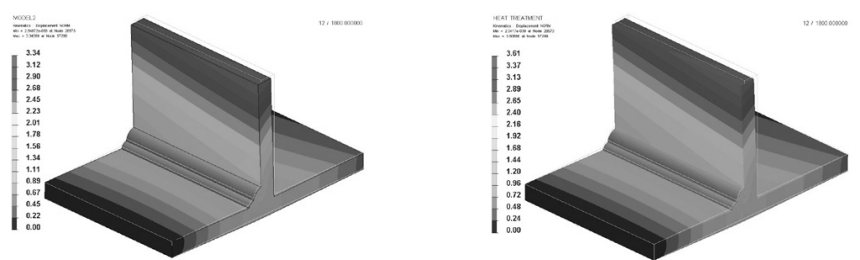

Rys. 5. Rozkład odkształceń całkowitych po procesie obróbki cieplnej złącza spawanego bez podgrzewania wstępnego (po lewej) oraz z podgrzewaniem wstępnym do $150^{\circ} \mathrm{C}$ (po prawej), tabl. V

Fig. 5. Mean distortion distribution after PWHT of T-joint welded without preheating (on the left) and with preheating up to $150^{\circ} \mathrm{C}$ (on the right), tabl. V

Tablica V. Wartości odkształcenia całkowitego oraz w poszczególnych osiach złączy teowych blach o grubości 10 mm ze stali S355J2G3 metodą MAG po procesie spawania i obróbce cieplnej w zależności od zastosowanego wariantu technologicznego, rys. 5

Table V. Values of mean distortions and in different axes on S355J2G3 $10 \mathrm{~mm}$ thick plates T-joint MAG welded after welding and PWHT according to used technological variant, fig. 5

\begin{tabular}{|c|c|c|c|c|}
\hline \multirow{3}{*}{$\begin{array}{l}\text { Rodzaj/charakter } \\
\text { odkształcenia }\end{array}$} & \multicolumn{4}{|c|}{ Wartość odkształcenia [mm] } \\
\hline & \multicolumn{2}{|c|}{ wariant bez podgrzewania wstępnego } & \multicolumn{2}{|c|}{ z podgrzewaniem wstępnym $\left(150^{\circ} \mathrm{C}\right)$} \\
\hline & $\min$. & $\max$. & $\min$. & $\max$. \\
\hline \multirow{2}{*}{$\begin{array}{l}\text { całkowite } \\
\text { - po spawaniu } \\
\text { - po obróbce cieplnej }\end{array}$} & 0 & 3,34 & 0 & 3,6 \\
\hline & 0 & 3,35 & 0 & 3,6 \\
\hline \multirow{2}{*}{$\begin{array}{l}\text { w osi X (poprzeczne) } \\
\text { - po spawaniu } \\
\text { - po obróbce cieplnej }\end{array}$} & 0 & 3,34 & 0 & 3,6 \\
\hline & $-0,17$ & 2,86 & $-0,2$ & 0,06 \\
\hline \multirow{2}{*}{$\begin{array}{l}\text { w osi Y (wzdłużne) } \\
\text { - po spawaniu } \\
\text { - po obróbce cieplnej }\end{array}$} & $-0,35$ & 0,32 & $-0,33$ & 0,35 \\
\hline & $-0,36$ & 0,3 & $-0,35$ & 0,32 \\
\hline \multirow{2}{*}{$\begin{array}{l}\text { w osi Z } \\
\text { - po spawaniu } \\
\text { - po obróbce cieplnej }\end{array}$} & $-1,71$ & 0,04 & $-1,86$ & 0,04 \\
\hline & $-1,74$ & 0,03 & $-1,88$ & 0,03 \\
\hline
\end{tabular}


Tablica VI. Wartości naprężeń zredukowanych i średnich w poszczególnych etapach spawania złączy teowych blach o grubości $10 \mathrm{~mm}$ ze stali S355J2G3 metodą MAG w zależności od zastosowanego wariantu technologicznego, rys. 6

Table VI. Values of VonMises and mean stresses on S355J2G3 $10 \mathrm{~mm}$ thick plates T-joint MAG welded according to used technological variant, fig. 6

\begin{tabular}{|c|c|c|c|c|}
\hline \multirow{3}{*}{$\begin{array}{l}\text { Etap spawania } \\
\text { i rodzaj naprężeń }\end{array}$} & \multicolumn{4}{|c|}{ Wartość naprężeń [MPa] } \\
\hline & \multicolumn{2}{|c|}{ wariant bez podgrzewania wstępnego } & \multicolumn{2}{|c|}{ z podgrzewaniem wstępnym $\left(150^{\circ} \mathrm{C}\right)$} \\
\hline & $\min$. & $\max$. & $\min$. & $\max$. \\
\hline \multirow{2}{*}{$\begin{array}{l}\text { po } 1 \text { ściegu } \\
\text { - zredukowane (VonMises) } \\
\text { - średnie }\end{array}$} & 0 & 606 & 0 & 555 \\
\hline & -324 & 374 & -312 & 350 \\
\hline \multirow{2}{*}{$\begin{array}{l}\text { po } 2 \text { ściegu } \\
\text { - zredukowane (VonMises) } \\
\text { - średnie }\end{array}$} & 0 & 714 & 0 & 652 \\
\hline & -331 & 416 & -347 & 390 \\
\hline \multirow{2}{*}{$\begin{array}{l}\text { po } 3 \text { ściegu } \\
\text { - zredukowane (VonMises) } \\
\text { - średnie }\end{array}$} & 0 & 667 & 0 & 623 \\
\hline & -375 & 434 & -366 & 407 \\
\hline \multirow{2}{*}{$\begin{array}{l}\text { po obróbce } \\
\text { - zredukowane (VonMises) } \\
\text { - średnie }\end{array}$} & 0 & 233 & 0 & 229 \\
\hline & -178 & $\begin{array}{c}1 \\
91\end{array}$ & -172 & 180 \\
\hline
\end{tabular}
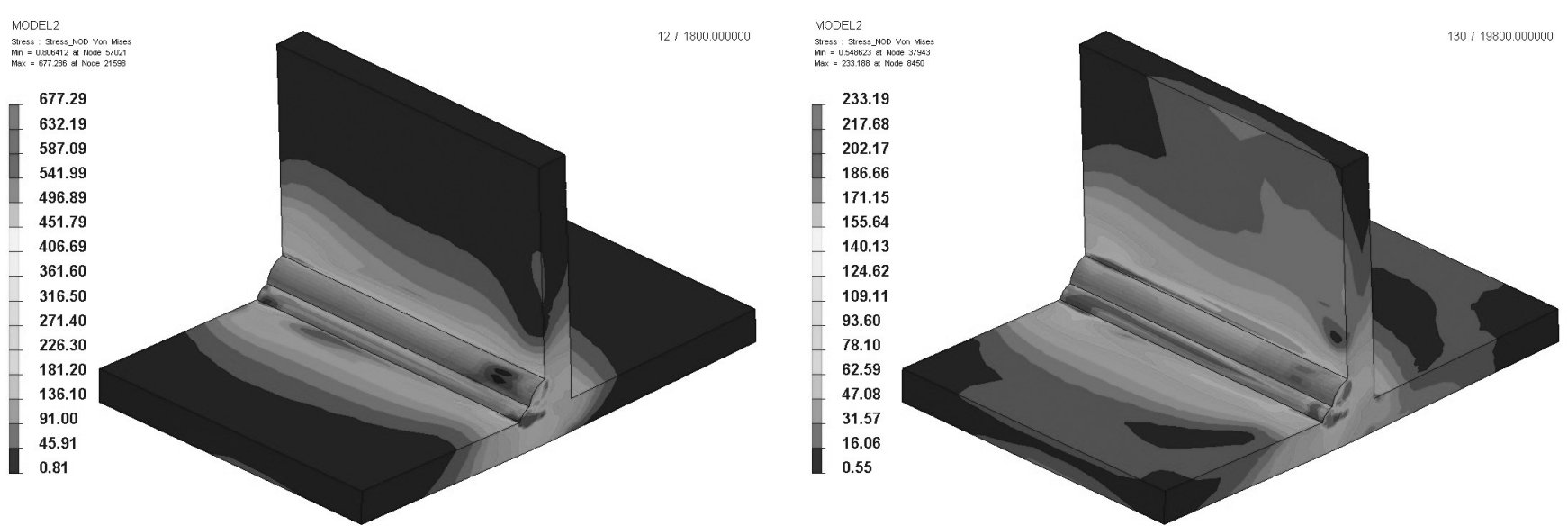

Rys. 6. Rozkład naprężeń zredukowanych (VonMises) po procesie spawania oraz obróbki cieplnej złączy teowych blach o grubości $10 \mathrm{~mm}$ ze stali S355J2G3 metodą MAG spawanego bez podgrzewania wstępnego, tabl. VI

Fig. 6. VonMises stresses distribution after welding and PWHT of T-joint welded without preheating, tabl. VI

\section{Podsumowanie}

Przeprowadzone analizy numeryczne procesu spawania wielościegowego złączy teowych blach o grubości $10 \mathrm{~mm}$ ze stali S355J2G3 metodą MAG spawanych bez podgrzewania wstępnego oraz z podgrzewaniem wstępnym wykazały, że istnieje możliwość analizy wielu czynników wpływających na przebieg procesu oraz otrzymane wyniki, które całkowicie zgadzają się z posiadaną przez spawalnika wiedzą inżynierską. Wyniki tych analiz dostarczają mu również dodatkowych informacji dotyczących przebiegu procesu jak również ewolucji odkształceń i naprężeń w zależności od stosowanych warunków technologicznych (tutaj zastosowanie podgrzewania wstępnego oraz obróbki cieplnej złącza po procesie spawania). Same analizy stanowią być może o kwestiach oczywistych, natomiast są bardzo dobrym przykładem jak szczegółowo i na wielu parametrach spawalnik jest w stanie oprzeć argumenty swoich dalszych działań.

Analizując rozkład faz metalurgicznych i ich procentowy udział w złączu, widoczne jest zarówno korzystne działanie procesu obróbki cieplnej - spadek zawartości martenzytu przy zastosowaniu podgrzewania wstępnego z wartości maksymalnie prawie $75 \%$ do wartości około $39 \%$. Również zastosowanie obróbki cieplnej po spawaniu jest wyraźnie widoczne w rozkładzie faz metalurgicznych i maksymalnych zawartościach poszczególnych faz. Struktura martenzytyczna i bainityczna powstała po procesie spawania zastąpiona zostaje strukturami odpuszczonymi, tablica III.

Zmiany te widoczne są również w wynikach obliczeń rozkładu twardości w analizowanym złączu. W obu analizowanych przypadkach maksymalna twardość po obróbce cieplnej znacząco spada. W przypadku złącza spawanego bez podgrzewania wstępnego jest to spadek z niebezpiecznych 420HV do dopuszczalnego poziomu około $291 \mathrm{HV}$, natomiast w przypadku zastosowania podgrzewania wstępnego zmiana ta jest łagodniejsza: z 370 do $222 \mathrm{HV}$, tablica IV.

Analiza mechaniczna również niesie ze sobą wiele informacji zgodnych z wynikami analizy termo-metalurgicznej ale i założeniami stosowanych zabiegów technologicznych takich jak podgrzewanie wstępne złącza oraz obróbka cieplna 
po procesie spawania. W przypadku analizy odkształceń złącza, wiadomym jest że w tego typu złączach za wielkość i charakter odkształceń odpowiada głównie sposób zamocowania elementów do spawania oraz liczba ściegów i ilość ciepła wprowadzona do złącza. Ponieważ oba warianty technologiczne analizowane były bez usztywnienia (zamocowania) złącza, stąd też wyniki odkształceń i ich rozkład jest bardzo zbliżony. Nie zmienia go również przeprowadzona po procesie spawania obróbka cieplna (prowadzona również bez usztywnienia złącza).

Podobnie przedstawia się sytuacja w przypadku analizy rozkładu naprężeń w spawanych złączach. Wielkość ta również zależy w dużym stopniu od sposobu zamocowania elementów do spawania oraz liczby ściegów i ilości ciepła wprowadzonego do złącza. Dodatkowo wpływ na wielkość i rozkład naprężeń mają również obliczane w analizie termo-metalurgicznej rozkłady faz metalurgicznych. Otrzymujemy również dodatkową możliwość analizy tych naprężeń w trakcie spawania. Takie pomiary są niemożliwe do wykonania w przypadku realnych prób spawania a dają wiele cennych informacji np. o przyczynach powstawania pęknięć czy odkształceń. Również w tym przypadku widoczne są, choć niewielkie, różnice w wartości maksymalnych naprężeń w analizowanych przypadkach a zastosowanie obróbki cieplnej złącza po spawania obniża wartości naprężeń z poziomu około 620-670 MPa do wartości 180-191 MPa, tablica VI.

Zatem w przeprowadzonych analizach potwierdzono, że zarówno podgrzewanie wstępne jaki i obróbka cieplna złączy spawanych pozwala na obniżenie poziomu naprężeń w złączach. Jednak dodatkową zaletą prowadzenia tego typu analiz jest już wspomniana, znacznie większa liczba danych, którą otrzymujemy analizując wirtualnie taki proces. Nic więc nie stoi na przeszkodzie do tego, żeby użyć tego narzędzia do optymalizacji całego procesu spawania i poszukiwania najlepszych rozwiązań przy znacznie ograniczonych kosztach wynikających z braku konieczności prowadzenia realnych prób spawania a następnie badań laboratoryjnych.

\section{Literatura}

[1] Kong F., Ma J., Kovacevic R.: Numerical and experimental study of thermally induced residua stress in the hybrid laser-GMA welding process, Journal of Materials Processing Technology 211 (2011) 1102-1111.

[2] Kik T.: Numerical analysis of MIG welding of butt joints in aluminium alloy, Biuletyn Instytutu Spawalnictwa, (2014) R. 58 nr 3, pp. 37-49.

[3] ESI Group: SYSWELD reference manual, digital version SYSWELD 2015.1

[4] Ferenc K., Ferenc J.: Konstrukcje spawane, projektowanie połączeń. WNT 2000.

[5] Goldak J., Breiguine V., Dai N., Zhou J.: (1996). Thermal stress analysis in welds for hot cracking. ASME, Pressure Vessels and Piping Division PVP. Proceeding of the 1996 ASME PVP Conf., July 2, 1-26, Montreal.

[6] Wu CS, Wang HG, Zhang YM: A new heat source model for keyhole plasma arc welding in FEM analysis of the temperature profile. Weld $\mathrm{J}$ 2006;85(12): 284s-91s.

[7] Böhme T., Dornscheidt C., Pretorius T., Scharlack J., Spelleken F.: Modeling, Simulation and Experimental Studies of Distortions, Residual Stresses and Hydrogen Diffusion During Laser Welding of As-Rolled Steels, Materials Science and Technology, 3/2012.

[8] Slováček M., Kik T.: Wykorzystanie analiz numerycznych procesów spawania jako wsparcia technicznego w przemyśle. Cz. 1, Wstęp do zagadnienia symulacji numerycznych procesów spawania. Biuletyn Instytutu Spawalnictwa 2015 R. 59 nr 4, s. 42-47.

[9] Kik T., Slováček M., Moravec J., Vaněk M.: Numerical Analysis of Residual Stresses and Distortions in Aluminium Alloy Welded Joints, Applied Mechanics and Materials, Vols. 809-810, 443-448 DOI: 10.4028/www.scientific.net/AMM.809-810.443.

[10] Kik T., Slováček M., Moravec J., Vaněk M.: Numerical Simulations of Heat Treatment Processes, Applied Mechanics and Materials, Vols. 809-810, 799-804 DOI: 10.4028/www.scientific.net/AMM.809-810.799.

[11] Kik T., Burda M.: Numerical simulation in laboratory research of welding processes as a tool for study CNT stability in molten metal. The First International Conference on Modern Manufacturing Technologies in Industrial Engineering. ModTech 2013, Sinaia, Romania, June 27-29, 2013. Book of abstracts. Red. C. Carausu. Iasi : Modtech Publishing House, 2013, s. 218 ( 2286-4369). 